\title{
KESULITAN MAHASISWA DALAM MEMAHAMI KONSEP GAYA DAN GERAK
}

\author{
Muhammad Reyza Arief Taqwa ${ }^{1 *}$, Muhammad Ibnu Shodiqin ${ }^{1,2}$, Abu \\ Zainuddin ${ }^{3}$
}

\author{
Universitas Negeri Malang $^{1 *}$, SMAN 1 Sumberpucung ${ }^{2}$, Universitas Negeri Surabaya ${ }^{3}$ \\ *Coressponding Author: reyza.arief.fmipa@um.ac.id
}

DOI: $10.24929 /$ lensa.v10i1.86

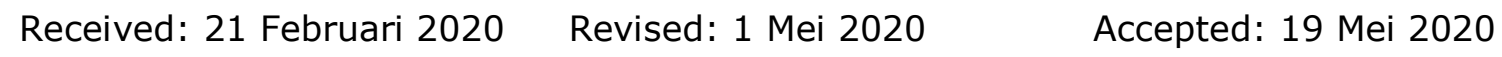

\begin{abstract}
ABSTRAK
Penelitian ini bertujuan untuk mengetahui pemahaman konsep dan mengungkap konsepsi mahasiswa pada topik gaya dan gerak. Untuk mencapai tujuan tersebut digunakan 25 soal pilihan ganda beralasan. Penelitian ini merupakan penelitian survei yang dilakukan pada 46 mahasiswa (22 mahasiswa S1 fisika dan 24 mahasiswa S1 pendidikan fisika). Hasil penelitian menunjukkan bahwa kemampuan mahasiswa dalam memahami konsep gaya dan gerak masih rendah. Hal ini diindikasi oleh skor rata-rata mahasiswa dalam menyelesaikan kasus terkait gaya dan gerak hanya 30,35. Selain itu, respon yang diberikan oleh siswa juga menunjukkan kesulitan dalam memahami konsep gaya dan gerak, dan beberapa kesulitan yang terjadi di antaranya adalah dalam menggambarkan arah gaya normal. Siswa juga sulit memahami hukum kedua Newton karena salah menentukan arah percepatan. Dalam memahami hukum ketiga Newton, siswa salah menggambarkan diagram bebas benda (Free-Body Diagrams') dan membandingkan gaya hasil interaksi. Hasil penelitian ini menunjukkan bahwa pembelajaran perlu dirancang dengan hati-hati karena banyak siswa mengalami kesulitan dalam memahami konsep-konsep fisika.
\end{abstract}

Kata Kunci: Kesulitan, pemahaman konsep, gaya dan gerak.

\section{ABSTRACT}

This study aims to determine students' conceptual understanding and exposing students' conception on the topic of force and motion. To achieve these objectives used 25 MCQs reasoned. This study is a survey of 46 students (22 physics students and 24 physics education students). The results showed that the students' ability to understand the concepts of force and motion is still very low. It is indicated by an average score of students in solving cases related to force and motion only 30.35. In addition, the responses were given by students also show difficulties in understanding the concepts of force and motion, and some of the difficulties that occur among them are in describing the direction of normal force. Students' were also difficult in understanding Newton's second law because it was wrong in determining the direction of acceleration. In understanding Newton's third law, students' misrepresent free-body diagrams and compare the force of the result of interaction. The results of this study indicate that learning needs to be carefully designed because many students have difficulty in understanding the concepts of physics.

Keywords: Difficulties, conceptual understanding, force and motion.

\section{PENDAHULUAN}

Pemahaman mahasiswa terkait konsep fisika telah menjadi fokus beberapa peneliti (Bayraktar, 2009; Hestenes, Wells, \& Swackhamer, 1992; Trowbridge \& McDermott, 1981; Taqwa et al., 2017) termasuk konsep gaya dan gerak. Kosep gaya dan gerak merupakan konsep fundamental dalam fisika (Galili \& Bar, 1992) dan memiliki peranan penting dalam menjelaskan banyak fenomena yang ada dikehidupan sehari-hari. Sayangnya, dalam menjelaskan fenomena siswa sering membangun penalaran yang 
sering kali tidak sesuai dengan konsep ilmiah (Başer, 2006) yang disebut dengan beberapa istilah seperti preconception (Clement, 1982), alternative frameworks (Muthukrishna et al., 1993), alternative conception (Dykstra et al., 1992; Heller \& Huffman, 1995), atau miskonsepsi (Andre \& Ding, 1991; Clement et al., 1989; Taqwa et al., 2017). Hal tersebut terjadi sebelum siswa melakukan pembelajran sains, sehingga siswa datang ke kelas telah membawa pengetahuan yang diperoleh dari pengalamannya (Docktor \& Mestre, 2014; Loverude et al., 2003; Radovanović \& Sliško, 2013; Çepni \& Şahin, 2012; Çepni et al., 2010; Unual \& Costu, 2005). Konsep gaya dan gerak merupakan bagian penting yang harus dikuasai oleh siswa untuk memahami konsep lain yang terkait. Kendati demikian, penguasaan konsep mereka masih rendah (Thornton \& Sokoloff, 1998). Salah satu penyebab rendahnya penguasaan konsep siswa adalah adanya miskonsepi (Beynon, 1994; Chambers Andre, T., 1997; diSessa, 1993; Hake, 1998; Halloun \& Hestenes, 1985; Trowbridge \& McDermott, 1981; Viennot, 1979) akibat penalaran siswa yang tidak sesuai dengan konsep ilmiah dalam menjelaskan fenomena keseharian (K. Fisher, 1999; K. M. Fisher, 1985; Gilbert \& Watts, 1983; Helm, 1980; Thornton \& Sokoloff, 1998).

Miskonsepsi yang dialami siswa akan sulit untuk diubah jika guru tidak mengetahui miskonsepsi yang dialami oleh siswa terkait topik yang akan diajarkan (Alias \& Ibrahim, 2016). Mengenali miskonsepsi dan kesuliatan yang dialami oleh siswa menjadi bagian penting dalam proses pembelajaran (Eshach, 2014; Eshach, Lin, \& Tsai, 2016) agar pembelajaran yang dirancang dapat mencapai tujuan yang maksimal (Taqwa, 2017). Oleh karena itu, selama beberapa dekade terkahir banyak peneliti yang mencurahkan perhatiannya dalam mengidentifikasi miskonsepsi dan kesulitan.

Warkitri dalam Arief et al. (2012) menyatakan bahwa pada dasarnya kesulitan belajar merupakan kondisi dimana terdapat jarak antara keadaan ideal prestasi akademik siswa dengan prestasi akademik yang siswa peroleh. Kesulitan belajar dapat dimaknai sebagai keadaan dimana capaian kompetensi siswa lebih rendah dari standar yang diharapkan. Dalam konteks fisika sendiri, kesulitan pemahaman konsep merupakan keadaan dimana siswa gagal dalam mengonstruk konsep fisika secara komprehensif dan mendalam. Selain itu, terkadang siswa yang telah memiliki pengetahuan, namun dikarenakan pengetahuan yang dimiliki cenderung tidak utuh, kerap kali siswa gagal dalam memanggil pengetahuan yang telah mereka miliki. Hal tersebut menyebabkan gagalnya siswa dalam menyelesaikan permasalahan. Terutama jika siswa dihadapkan dengan permasalahan-permasalahan yang kompleks (Azizah et al., 2015).

Selama ini, siswa jarang diberikan soal mendasar terkait pemahaman konsep. Dalam mengerjakan soal biasanya siswa terfokus pada angka-angka dan satuan yang muncul (Linuwih \& Setiawan, 2010). Banyak siswa bahkan mahasiswa bingung dalam mengerjakan persoalan konsep mendasar tanpa angka. Oleh karena itu, dalam penelitian ini digunakan soal-soal konseptual yang mendasar, yang sebagian besar diberikan tanpa menyertakan angka. Soal-soal yag diberikan dirancang untuk mengetahui penguasaan konsep serta kosepsi yang diiliki siswa secara mendasar. Hal ini mengingat pentingnya mengenali konsepsi yang dimiliki oleh mahasiswa serta kesulitan yang masih dialami untuk kedepannya digunakan sebagai pertimbangan dalam merancang rencana pembelajaran yang baik. Dalam penelitian ini, alasan mahasiswa yang tidak sesuai dengan konsep ilmiah akan lebih diartikan sebagai indikasi kesulitan mahasiswa. 


\section{METODE}

Penelitian ini merupakan penelitian deskriptif dengan metode survei. Tujuan utama penelitian untuk mendeskripsikan pemahaman konsep mahasiswa terkait konsep gaya dan gerak serta kesulitan yang masih dialami. Penelitian deskriptif berkaitan dengan pengidentifikasian suatu fenomena, pengumpulan fakta dan meramalkan hubungan dalam dan antar variabel. Metode survei digunakan untuk memecahkan permasalahan dengan menggunakan data yang didapat (Sevilla, et al., 1993: 76).

Penelitian dilaksanakan di Universitas Negeri Malang. Subjek penelitian ini merupakan 46 mahasiswa yang sedang menjalani perkuliahan fisika dasar I. Subjek penelitian terdiri dari 22 mahasiswa S1 Fisika dan 24 mahasiswa S1 pendidikan fisika.

Penelitian ini merupakan bagian dari penelitian penerapan program resitasi yang bertujuan untuk mengembangkan soal-soal konseptual dan diterapkan setelah perkuliahan fisika dasar I di Universitas Negeri Malang. Namun sebelum mengembangkan dan menerapkan program resitasi, perlu dilakukan analisis pemahaman konsep mahasiswa terlebih dahulu. Untuk mengetahui tingkat pemahaman konsep serta kesulitan yang masih dialami oleh mahasiswa digunakan 25 soal pilihan ganda beralasan. Tabel 1 merupakan gambaran terkait topik, tema, dan kemampuan yang diuji.

Tabel 1. Tema dan Kemampuan yang Diuji dalam Tiap Topik

\begin{tabular}{|c|c|c|c|}
\hline Topik & Tema & Kemampuan yang Diuji & No. Soal \\
\hline $\begin{array}{l}\text { Identifikasi } \\
\text { Gaya }\end{array}$ & $\begin{array}{l}\text { Gaya } \\
\text { Normal }\end{array}$ & $\begin{array}{l}\text { Menentukan arah gaya normal pada objek yang } \\
\text { ada pada bidang vertikal dan horizontal }\end{array}$ & 22 \\
\hline $\begin{array}{l}\text { Hukum I } \\
\text { Newton }\end{array}$ & $\begin{array}{l}\text { Gerak } \\
\text { benda pada } \\
\text { kerangka } \\
\text { non inersia }\end{array}$ & $\begin{array}{l}\text { Menganalisis grafik kecepatan benda oleh } \\
\text { pengamat yang bergerak terhadap waktu selama } \\
\text { beberapa sekon sejak pengereman }\end{array}$ & 19 \\
\hline \multirow[t]{7}{*}{$\begin{array}{l}\text { Hukum II } \\
\text { Newton }\end{array}$} & \multirow[t]{4}{*}{$\begin{array}{l}\text { Resultan } \\
\text { gaya }\end{array}$} & $\begin{array}{l}\text { Menganalisis besar dan/atau arah resultan gaya } \\
\text { yang bekerja pada benda di atas landasan licin } \\
\text { (lintasan datar dan lintasan lengkung) }\end{array}$ & $\begin{array}{l}2,3,4, \\
12,16 \\
23\end{array}$ \\
\hline & & $\begin{array}{l}\text { Menganalisis hubungan gaya-gaya yang bekerja } \\
\text { pada benda yang bergerak dengan kelajuan tetap }\end{array}$ & 5 \\
\hline & & $\begin{array}{l}\text { Menganalisis arah } \vec{v}, \vec{a} \text {, dan } \vec{F} \text { pada benda yang } \\
\text { bergerak melingkar dengan laju konstan }\end{array}$ & 7 \\
\hline & & $\begin{array}{l}\text { Merepresentasikan grafik } \vec{v}-t \text { dan kasus gerak } \\
\text { vertikal ke dalam grafik } \vec{F}-t\end{array}$ & 1,14 \\
\hline & Percepatan & $\begin{array}{l}\text { Menganalisis besar dan/atau arah percepatan } \\
\text { benda dengan kelajuan tetap, resultan gaya tetap } \\
\text { namun massa berubah, percepatan tangensial, } \\
\text { dan benda jatuh bebas }\end{array}$ & $\begin{array}{l}6,9, \\
13,\end{array}$ \\
\hline & $\begin{array}{l}\text { Gaya } \\
\text { tegangan } \\
\text { tali }\end{array}$ & $\begin{array}{l}\text { Menganalisis besar gaya tegangan tali pada benda } \\
\text { yang berada di atas suatu bidang licin horizontal } \\
\text { dan pada benda yang mengalami percepatan }\end{array}$ & $\begin{array}{l}18,20, \\
21\end{array}$ \\
\hline & $\begin{array}{l}\text { Gaya } \\
\text { normal }\end{array}$ & $\begin{array}{l}\text { Menentukan gaya normal pada benda yang berada } \\
\text { di lintasan lengkung, dan pada sistem yang } \\
\text { bergerak dengan percepatan konstan }\end{array}$ & $\begin{array}{l}8,10 \\
11,25\end{array}$ \\
\hline
\end{tabular}




\begin{tabular}{llll}
\hline Topik & Tema & Kemampuan yang Diuji & No. Soal \\
\hline $\begin{array}{l}\text { Hukum III } \\
\text { Newton }\end{array}$ & $\begin{array}{l}\text { Gaya-gaya } \\
\text { hasil } \\
\text { interaksi }\end{array}$ & $\begin{array}{l}\text { Menentukan kemungkinan koin tetap menempel di } \\
\text { atas bidang yang bergerak melingkar }\end{array}$ & 17 \\
\hline & & $\begin{array}{l}\text { Mentukan free body diagram pada benda yang } \\
\text { didorong oleh benda lain yang dikenai suatu gaya }\end{array}$ & 15 \\
\hline & $\begin{array}{l}\text { bekerja pada anak yang sedang melakukan } \\
\text { permainan tarik tambang }\end{array}$ & 24 \\
\hline
\end{tabular}

Soal-soal yang digunakan dalam penelitian merupakan pengembangan soal yang digunakan sebagai standar tes di Universitas Negeri Malang. Soal dirancang dengan mengadaptasi dari penelitian-penelitian yang telah dilakukan sebelumnya, seperti soalsoal FCI, ataupun dari buku-buku fisika universitas. Soal yang dikembangkan ini terdiri dari 25 butir soal pilihan ganda yang telah diujikan pada 162 mahasiswa fisika dan pendidikan fisika di Universitas Negeri Malang. Hasil analisis butir soal terkait informasi daya beda dan tingkat kesukaran disajikan dalam Tabel 2.

Tabel 2. Analisis Daya Beda dan Kesukaran

\begin{tabular}{llll}
\hline \multicolumn{1}{c}{ Kaya Beda } & \multicolumn{2}{c}{ Tingkat Kesukaran } \\
\hline \multicolumn{1}{c}{ Kategori } & \multicolumn{1}{c}{ No. Soal } & Kategori & \multicolumn{1}{c}{ No. Soal } \\
\hline Sangat baik & $1,3,4,7,8,10,13$, & Mudah & 2 \\
Baik & $15,24,25$ & & \\
& $5,6,9,12,16,22$ & Sedang & $1,3,4,5,6,7,8$, \\
& & & $10,11,12,13,15$, \\
& & & $16,17,19,20,21$, \\
Cukup & $2,11,14,20,23$ & Sukar & $22,24,25$ \\
Jelek & 17,18 & & $9,14,18,23$ \\
\hline
\end{tabular}

Dari analisis data uji empiris diperoleh 24 soal dengan kriteria valid (sig. 0,01). Hanya satu soal yakni nomor 18 dengan koefesien korelasi Pearson product moment sebesar 0,033 dan sig. $=0,674$. Namun dalam penelitian, soal ini tetap digunakan mengingat soal ini merupakan soal yang sudah menjadi standar Internasional hasil pengembangan instrumen FCI. Selain itu, soal ini penting untuk mengukur kemampuan mahasiswa dalam memahami konsep hukum II Newton. Sedangkan tingkat keandalan instrumen ditunjukkan dari nilai Cronbach's Alpha (Hair et al., 2010: 92) yang bernilai nol sampai satu. Dalam sebuah instrumen nilai Cronbach's Alpha minimal adalah 0,7. Hasil analisis yang dilakukan menunjukkan bahwa instrumen yang digunakan merupakan instrumen yang sangat andal karena nilai Cronbach's Alpha > 0,80 (Hair et al., 2010: 125).

Hasil analsis terkait daya beda tiap butir soal diperoleh soal dengan kategori sangat baik, baik, cukup dan jelek dan tingkat kesukaran diperoleh soal dengan kriteria sukar, sedang dan mudah seperti yang ditunjukkan Tabel 2. Dari hasil analisis daya terdapat dua soal yakni nomor 17 dan 18 yang memiliki kriteria jelek. Kedua soal tersebut sulit membedakan siswa dengan kemampuan tinggi dan rendah.

Dalam penelitian ini diperoleh data skor pemahaman konsep gaya dan gerak mahasiswa yang merupakan data kuantitatif. Selain itu diperoleh data alasan mahasiswa 28 I LENSA (Lentera Sains) Vol. 10, No.1, hlm. 25-39, 2020 
dalam menjawab soal. Alasan mahasiswa merupakan data kualitatif yang dapat mendukung data kuantitatif. Analisis data kuantitatif untuk mendeskripsikan data penguasaan konsep mahasiswa. Hal tersebut dilakukan dengan menentukan rata-rata, modus, nilai maksimum dan minimum, dan standar deviasi. Untuk data kualitatif, menurut Sugiyono (2014) dilakukan analisis mulai dari tahap pengumpulan data, reduksi data, penyajian data, dan penarikan kesimpulan seperti langkah pada analisis Miles and Huberman. Gambar 1 menunjukkan alur analisis data kualitatif yang dilakukan.

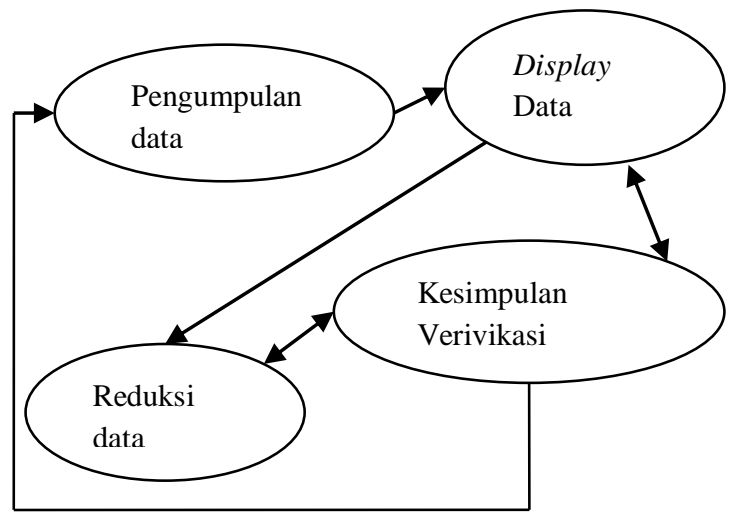

Gambar 1. Komponen dalam Analisis Data (Interactive Model)

Penelitian ini tidak dilakukan analisis data selama pengambilan data mengingat tujuan penelitian adalah untuk mengetahui tingkat pemahaman konsep mahasiswa dan kesulitan yang masih dialami. Pada tahap reduksi, dilakukan pemilihan data yang tepat untuk digunakan dalam analisis selanjutnya. Data direduksi untuk dipilih yang sekiranya sesuai dengan apa yang diteliti dan dilakukan juga proses penyederhanaan. Pada tahap penyajian data, data hasil reduksi dengan koding ditampilkan kembali secara naratif melalui bantuan uraian singkat, bagan, tabel atau grafik Sugiyono (2014). Pada tahap terakhir, kesimpulan diambil berdasarkan tahap penyajian data.

\section{HASIL DAN PEMBAHASAN}

\section{Pemahaman Konsep Gaya dan Gerak}

Dari hasil pemberian tes didapat bahwa skor penguasaan konsep mahasiswa terkait konsep gaya dan gerak masih tergolong rendah. Hal ini dapat dilihat dari rendahnya rata-rata skor mahasiswa serta alasan yang diberikan. Berikut disajikan informasi terkait statistik deskriptif pada Tabel 3, distribusi pilihan jawaban mahasiswa pada Tabel 4, dan frekuensi pada tiap rentang skor pada Gambar 2.

Tabel 3. Statistik Deskriptif Skor Pemahaman Konsep Gaya dan Gerak

\begin{tabular}{ll}
\hline Statistik & Nilai \\
\hline Minimum & 8,00 \\
Maksimum & 56,00 \\
Mean & 30,43 \\
Standar Deviasi & 9,92 \\
Median & 28,00 \\
Modus & 28,00 \\
\hline
\end{tabular}




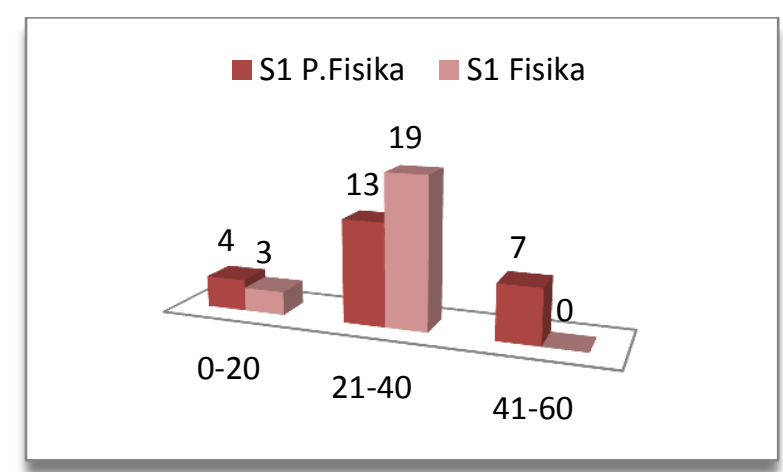

Gambar 2. Jumlah Mahasiswa Per Interval Skor

Tabel 3 menunjukkan deskriptif statistik skor mahasiswa. Merujuk pada rata-rata skor mahasiswa sebesar 30,43 menunjukkan bahwa penguasaan konsep mahasiswa terkait topik gaya dan gerak masih sangat rendah. Skor tertinggi mahasiswa dalam menjawab soal konseptual terkait gaya dan gerak hanya mencapai 56,00. Selain itu, Tabel 4 menunjukkan jumlah distribusi jawaban mahasiswa dalam menjawab soal. Dari tabel tersebut tampak bahwa hanya 5 dari 25 soal yang terjawab lebih dari $50 \%$ mahasiswa. Soal tersebut diantaranya nomor 1 yang terjawab dengan benar oleh 28 $(60,87 \%)$ mahasiswa, nomor 2 yang terjawab dengan benar oleh $39(84,78 \%)$ mahasiswa, nomor 11 yang terjawab dengan benar oleh $26(56,52 \%)$ mahasiswa, nomor 12 yang terjawab dengan benar oleh 25 (54,35\%) mahasiswa, dan nomor 24 yang terjawab dengan benar oleh $24(52,17 \%)$ mahasiswa. Gambar 2 menunjukkan jumlah mahasiswa dengan rentang skor 0-20 adalah sebanyak 4 mahasiswa pendidikan fisika dan 3 mahasiswa fisika, rentang skor 21-40 adalah sebanyak 13 mahasiswa pendidikan fisika dan 19 mahasiswa fisika, dan rentang rentang 41-60 adalah 7 orang mahasiswa pendidikan fisika dan tidak ada mahasiswa fisika yang skornya mencapai 41 . 
Tabel 4. Dsitribusi Pilihan Jawaban Mahasiswa

\begin{tabular}{|c|c|c|c|c|c|c|c|c|c|}
\hline \multirow{2}{*}{ No } & \multicolumn{7}{|c|}{ Opsi Jawaban } & \multirow{2}{*}{ Jumlah } & \multirow{2}{*}{$\begin{array}{c}\% \\
\text { benar }\end{array}$} \\
\hline & $\mathbf{A}$ & B & C & D & $\mathbf{E}$ & $\mathbf{F}$ & Kosong & & \\
\hline $\mathbf{1}$ & 1 & 4 & 3 & 10 & $28^{*}$ & NA & 0 & 46 & 60.87 \\
\hline 2 & 1 & 1 & $39 *$ & 2 & 2 & NA & 1 & 46 & 84.78 \\
\hline 3 & $7 *$ & 13 & 2 & 1 & 23 & NA & 0 & 46 & 15.22 \\
\hline 4 & 14 & 6 & $16 *$ & 4 & 6 & NA & & 46 & 34.78 \\
\hline 5 & 0 & 1 & $8^{*}$ & 32 & 5 & NA & & 46 & 17.39 \\
\hline 6 & 1 & 2 & 27 & $16 *$ & 0 & NA & & 46 & 34.78 \\
\hline 7 & 1 & 9 & 9 & $17 *$ & 9 & NA & 1 & 46 & 36.96 \\
\hline 8 & 10 & $16 *$ & 7 & 5 & 5 & NA & 3 & 46 & 34.78 \\
\hline 9 & 29 & 7 & 3 & $1 *$ & 2 & NA & 4 & 46 & 2.17 \\
\hline 10 & 9 & 3 & 0 & 26 & 6* & NA & 2 & 46 & 13.04 \\
\hline 11 & 5 & 2 & $26 *$ & 10 & 3 & NA & & 46 & 56.52 \\
\hline 12 & 2 & 12 & $25 *$ & 3 & 4 & NA & & 46 & 54.35 \\
\hline 13 & 29 & 4 & 1 & 3 & 2 & 6* & 1 & 46 & 13.04 \\
\hline 14 & 21 & 5 & 8 & 10 & $1^{*}$ & NA & 1 & 46 & 2.17 \\
\hline 15 & 3 & 34 & 5 & 0 & $4 *$ & NA & & 46 & 8.70 \\
\hline 16 & 14 & $19 *$ & 6 & 4 & 1 & NA & 2 & 46 & 41.30 \\
\hline 17 & 0 & 6 & 33* & 6 & 0 & NA & 1 & 46 & 71.74 \\
\hline 18 & 5 & 19 & 4 & $7^{*}$ & 9 & NA & 2 & 46 & 15.22 \\
\hline 19 & 15 & $11^{*}$ & 5 & 4 & 0 & 9 & 2 & 46 & 23.91 \\
\hline 20 & 8 & 7 & 3 & $14^{*}$ & 9 & 4 & 1 & 46 & 30.43 \\
\hline 21 & 7 & $7 *$ & 18 & 9 & 4 & NA & 1 & 46 & 15.22 \\
\hline 22 & 0 & 3 & 9 & $24 *$ & 2 & 8 & & 46 & 52.17 \\
\hline 23 & \multicolumn{8}{|c|}{$\begin{array}{c}\text { Pilihan jawaban berupa pilihan arah } 1 \text { sampai } 6 \text {, mahasiswa bebas } \\
\text { memilih lebih dari satu arah. Jawaban benar adalah arah } 4 \text {. }\end{array}$} & 8.70 \\
\hline 24 & 4 & $5 *$ & 8 & 3 & 25 & NA & 1 & 46 & 10.87 \\
\hline 25 & 14 & 3 & $9 *$ & 2 & 15 & NA & 3 & 46 & 19.57 \\
\hline \multicolumn{9}{|c|}{ Rata-rata } & $30.35 \%$ \\
\hline
\end{tabular}

Ket.: *Jumlah mahasiswa yang memilih opsi benar; NA: No Answer (opsi jawaban tidak dihadirkan)

Tidak hanya diindikasikan dari rendahnya skor yang diperoleh siswa, kesulitan mahasiswa juga diindikasikan dari respon jawaban yang masih banyak tidak sesuai secara konsep ilmiah dan menunjukkan lemahnya pemahaman yang dimilliki. Bahkan mahasiswa yang memilih opsi jawaban benar masih ada yang memberikan alasan yang belum tepat. Dalam artikel ini akan dibahas kesulitan secara umum yang masih dialami oleh mahasiswa pada beberapa tema, seperti menentukan resultan gaya, menerapkan hukum II Newton dalam menentukan percepatan dan gaya normal, dan hukum III Newton.

\section{Menentukan Gaya Normal}

Terdapat satu soal yang digunakan untuk mengukur kemampuan mahasiswa dalam mengidentifikasi gaya normal (perhatikan Gambar 3). Soal difokuskan untuk mengukur kemampuan mahasiswa dalam menentukan arah gaya normal pada benda yang berada di bidang datar dan vertikal. Dalam menjawab soal sederhana ini, mahasiswa masih banyak mengalami kesulitan yang diindikasi dari respon jawaban yang diberikan seperti 
(1) menggambarakn gaya normal pada pusat massa benda (Gambar 4(a)), (2) menggambarkan gaya normal diluar benda yang menjadi fokus persoalan (Gambar 4 (b)).

Sebatang kayu disandarkan pada dinding dengan membentuk sudut $45^{\circ}$ terhadap lantai seperti pada gambar.

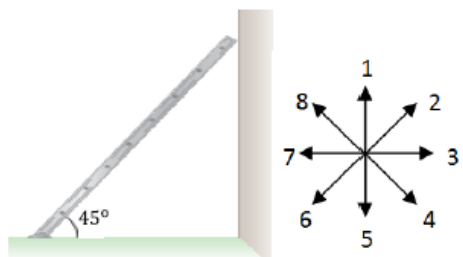

Arah gaya normal pada kayu oleh lantai dan dinding secara berurutan dinyatakan oleh garis nomor ....
(A) 2 dan 8
(B) 2 dan 6
(C) 1 dan 8
(D) 1 dan 7
(E) 2 dan 7
(F) 8 dan 8

Gambar 3. Soal nomor 22 untuk melihat kemampuan mahasiswa dalam mengidentifikasi gaya normal

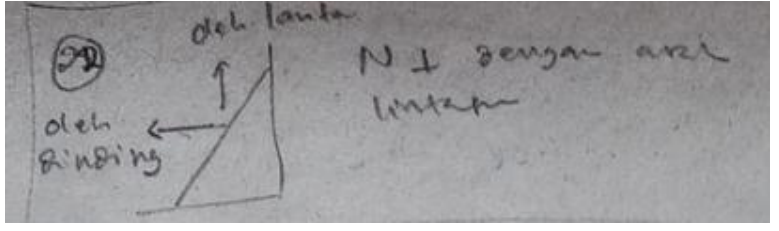

(a)

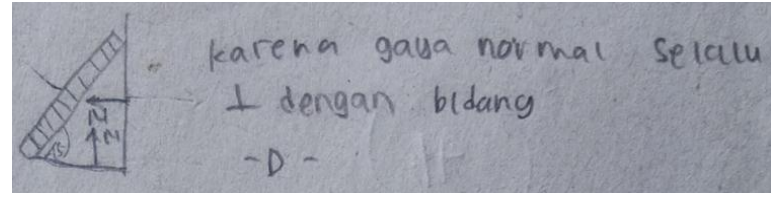

(b)

Gambar 4. Kesalahan mahasiswa dalam menjawab soal nomor 22, (a) melukis gaya normal pada pusat massa, dan (b) melukis gaya normal di luar objek.

Kesulitan mahasiswa dalam menentukan arah gaya normal ini telah beberapa kali diteliti. Dari penelitian Minstrell (1982) menunjukkan bahwa siswa sering kali beranggapan bahwa benda yang diam akan mendapatkan gaya normal hanya saat berinteraksi dengan permukaan diam. Siswa masih sering mengalami kesulitan dalam memahami konsep munculnya gaya normal (Kusyanti, 2013). Bahkan Stein et al., (2008) menemukan bahwa dari 305 siswa terdapat 40\% siswa yang menyatakan tidak ada gaya normal yang bekerja pada benda di atas bidang datar.

\section{Menerapkan Hukum II Newton untuk Menentukan Gaya Normal}

Ada beberapa tema yang diujikan dalam topik hukum II Newton, diantaranya adalah menentukan resultan gaya, percepatan, gaya tegangan tali, gaya normal dan gaya gesek (lihat Tabel 1). Dalam penelitian ini ditemukan kesulitan yang dialami mahasiswa dalam menentukan besar gaya normal karena kesalahpahaman dalam menentukan percepatan yang dialami objek meskipun sudah benar dalam mengidentifikasi gaya. Pada soal nomor 10 mahasiswa diminta untuk menentukan besar gaya normal yang bekerja pada sebuah benda yang menggelinding pada bidang lengkung saat di titik terendah (Gambar 5). Beberapa kesalahan yang ditemukan diantaranya (1) mahasiswa yang memilih opsi A berpikir bahwa besar gaya normal pada benda yang bergerak di 
lintasan lengkung selalu nol; (2) mahasiswa yang memilih opsi B berpikir bahwa pada saat di titik terendah bidang lengkung objek mengalami gaya normal yang sama dengan gaya sentripetal (Gambar 6(a)); (3) mahasiswa yang memilih opsi D berpikir bahwa pada saat di titik terendah bidang lengkung objek mengalami gaya normal yang sama dengan berat benda (Gambar 6(b)). Dalam menjawab soal nomor 10 ini kebanyakan mahasiswa berpikir bahwa pada titik terendah benda tidak mengalami percepatan, sehingga diperoleh besar gaya normal sama dengan gaya berat. Terdapat $26(56,52 \%)$ mahasiswa yang memilih opsi D. Opsi D mewakili konsepsi mahasiswa yang meganggap bahwa gaya normal pada saat di titik terendah bidang lengkung adalah sama dengan gaya berat karena tidak mengalami percepatan. Padahal pada saat di titik terendah benda mengalami percepatan yang arahnya menuju pusat (percepatan sentripetal), sehingga akan diperoleh bahwa pada titik B besar gaya normal yang di alami benda adalah 7,8 N. Hal ini menunjukkan bahwa dalam menggunakan konsep hukum II Newton tanpa memahami ide-ide kinematika terutama konsep percepatan sehingga mahasiswa mengalami kesalahan dalam menyelesaikan permasalahan.

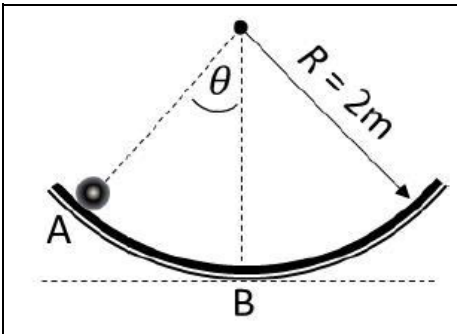

adalah ... N.
Sebuah bola bermassa $0,6 \mathrm{~kg}$ dilepaskan dari titik $A, \tan \theta=$ $3 / 4$ melalui lintasan yang cukup kasar berupa bagian lingkaran dengan jari-jari $2 \mathrm{~m}$. Koefisien gesekan kinetis antara permukaan bola dan landasan di sekitar titik B sebesar 0,2 dan kelajuan bola ketika di titik terbawah (B) sebesar $\sqrt{ } 6 \mathrm{~m} / \mathrm{s}$. Gunakan $g=10 \mathrm{~m} / \mathrm{s} 2$.

Besarnya gaya normal oleh landasan terhadap bola di titik B
(A) 0
(B) 1,8
(C) 4,2
(D) 6,0
(E) 7,8

Gambar 5. Soal nomor 10 untuk mengukur kemampuan mahasiswa dalam memahami hukum II Newton

Tabel 5. Distribusi jawaban mahasiswa dalam menjawab soal nomor 10 dan 18

\begin{tabular}{lll}
\hline \multirow{2}{*}{ Opsi } & \multicolumn{2}{c}{ Jumlah mahasiswa } \\
\cline { 2 - 3 } jawaban & Nomor 10 & Nomor 18 \\
\hline A & 9 & 5 \\
B & 3 & 19 \\
C & 0 & 4 \\
D & 26 & $7^{*}$ \\
E & $6^{*}$ & 9 \\
Kosong & 2 & 2 \\
\hline Jumlah & 46 & 46 \\
\hline
\end{tabular}

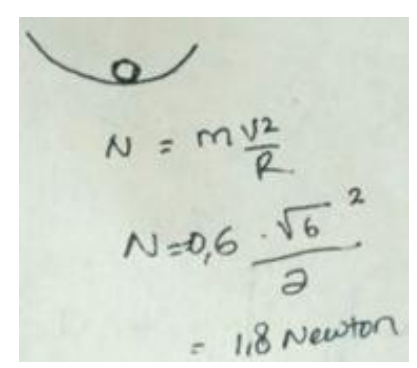

(a) 


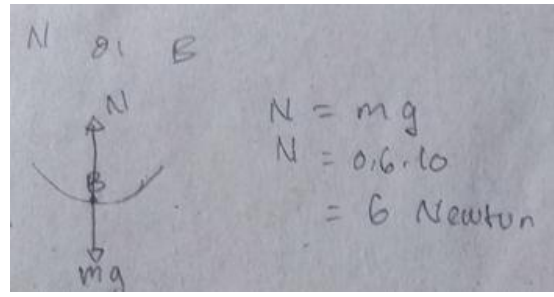

(b)

Gambar 6. Respon yang diberikan mahasiswa dalam memilih (a) opsi B (b) opsi D

\section{Menerapkan Hukum II Newton untuk Menentukan Pembacaan Skala Timbangan}

Dalam menjawab soal nomor 18 yang mengukur kemampuan mahasiswa dalam memahami konsep hukum II Newton juga banyak mengalami kesulitan. Pada soal ini mahasiswa diminta menentukan menghitung skala yang ditunjukkan oleh neraca pegas yang digunakan untuk mengukur berat benda di dalam sebuah lift yang bergerak ke bawah sambil diperlambat (lihat Gambar 6). Kesalahan yang banyak terjadi juga karena kekeliruan mahasiswa dalam konsep percepatan. Sebanyak $19(41,30 \%)$ mahasiswa yang telah benar dalam mengidentifikasi gaya tidak dapat menyelesaikan persoalan dengan benar dikarenakan kesalahan dalam menentukan arah percepatan (lihat Gambar 3). Mahasiswa yang memilih opsi B berpikir bahwa pada saat benda bergerak ke arah bawah sambil diperlambat, maka arah percepatan adalah ke bawah. Hal ini menyebabkan hasil perhitungan yang diperoleh menunjukkan bahwa pada neraca pegas digunakan untuk mengukur berat benda pada sistem yang bergerak ke bawah sambil diperlambat akan menunjukkan angka yang lebih kecil dari berat benda itu sendiri.

Seorang gadis menimbang ikan di dalam lift yang sedang turun ke lantai dasar. Ketika lift bergerak dengan kecepatan konstan, timbangan menunjuk angka $5 \mathrm{~N}$. Angka berapa yang akan ia dapati saat lift diperlambat $2 \mathrm{~m} / \mathrm{s}^{2}$ hingga berhenti? Anggap g $=10 \mathrm{~m} / \mathrm{s}^{2}$.
(A) $3 \mathrm{~N}$
(B) $4 \mathrm{~N}$
(C) $5 \mathrm{~N}$
(D) $6 \mathrm{~N}$
(E) $7 \mathrm{~N}$

Gambar 7. Soal nomor 18 untuk mengukur pemahaman tentang hukum II Newton

Kesalahan-kesalahan mahasiswa dalam menjawab soal nomor 10 dan 18 mengindikasikan bahwa masih banyak mahasiswa yang mengalami kesalahan dalam menentukan percepatan benda pada saat berada di titik terendah suatu bidang lengkung sehingga keliru pula dalam menyelesaikan persoalan terkait hukum II Newton. Temuan ini mendukung pernyatan Sutopo (2012) bahwa penting menguasai konsep posisi, kecepatan dan percepatan untuk dapat menguasai mekanika, tak terkecuali dalam menyelesaikan permasalahan dinamika partikel. Karna penguasaan ide-ide kinematika masih diperlukan dalam menyelesaikan persoalan dinamika partikel.

\section{Hukum III Newton dan Gaya Interaksi}

Terdapat dua buah soal yang digunakan untuk melihat kemampuan mahasiswa dalam memahami konsep hukum III Newton dengan konteks yang berbeda (lihat tabel 1) yakni nomor 15 dan 24 . Pada soal nomor 15 , banyak mahasiswa yang keliru dalam menggambarkan free-body diamgrams pada benda B (lihat Gambar 8). Sebagian besar mahasiswa beranggapan bahwa gaya dorong $P$ yang diberikan pada balok $A$ juga bekerja pada balok B. Dari pilihan opsi jawaban dan alasan yang diberikan, terlihat bahwa mahasiswa masih belum memegang konsep bahwa gaya merupakan hasil interaksi. Hanya $4(8,69 \%)$ mahasiswa yang benar dalam mengidentifikasi gaya. Hal ini 
menyebabkan kekeliruan mahasiswa dalam mengonstruksi free-body diagrams (Rosengrant et al., 2009).

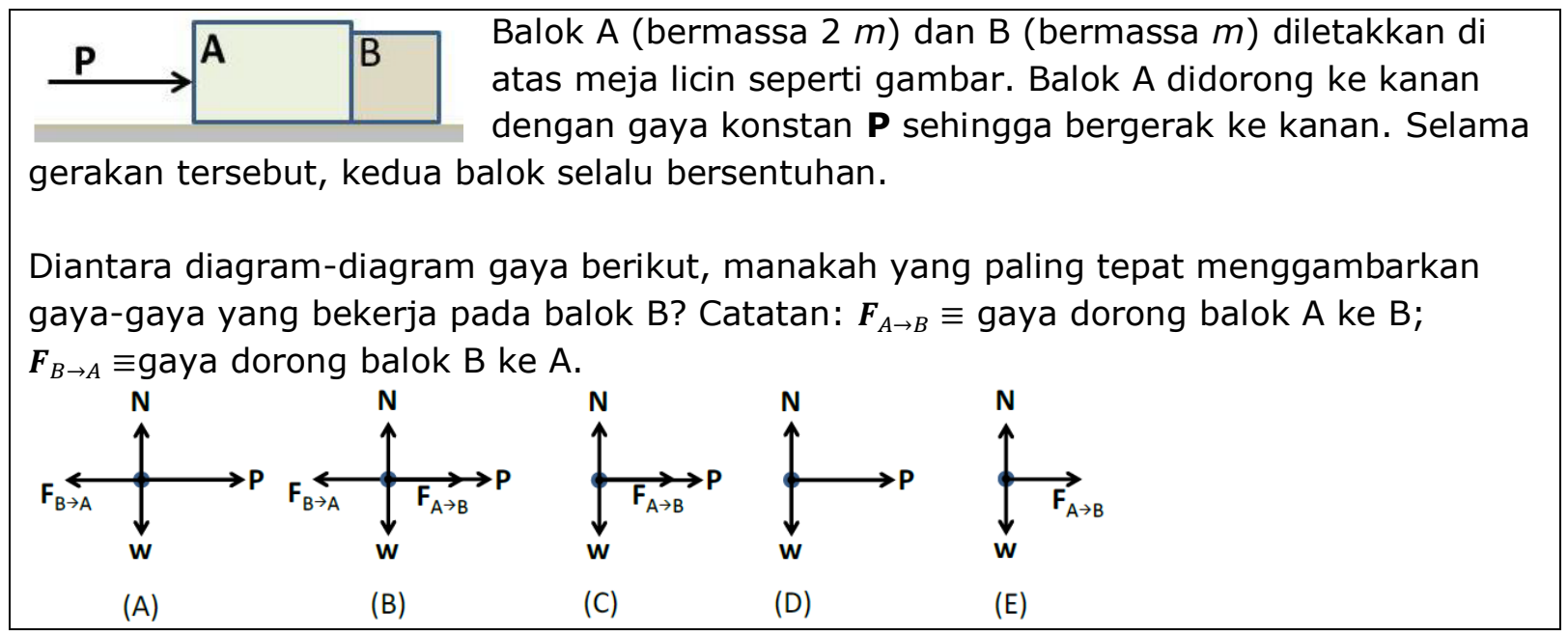

Gambar 8. Soal nomor 15 yang digunakan untu mengukur pemahaman tentang hukum III Newton (adaptasi : Taqwa, et al, 2017)

Bukan hanya kesulitan dalam mengidentifikasi gaya hasil interaksi dan menuangkan dalam free-body diagram, soal nomor 24 juga menunjukkan kelemahan mahasiswa dalam memahami konsep hukum III Newton yang ditunjukkan dengan kekeliruan mahasiswa dalam membandingkan besar gaya hasil interaksi. Soal ini diberikan untuk melihat kemampuan mahasiswa dalam membandingkan besar gaya yang timbul, yakni gaya tarik antar anak A dan B serta gaya gesek yang timbul pada kaki kedua anak yang sedang melakukan kegiatan tarik tambang (Gambar 9).

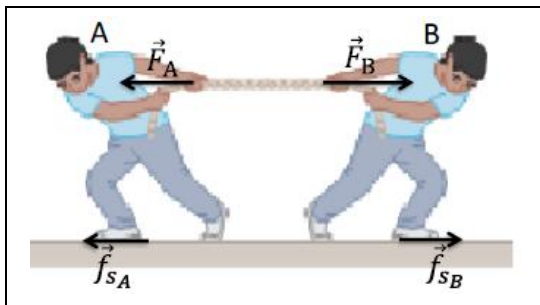

Dua siswa A dan B bermain tarik tambang seperti ditunjukkan pada gambar. Gaya $\vec{F}_{A(B)}$ menyatakan gaya tarikan oleh A (B), sedangkan gaya $\vec{f}_{S A(B)}$ menyatakan gaya gesek statis maksimum yang dapat diupayakan oleh A (B). Jika siswa A akhirnya kalah, manakah pernyataan berikut yang benar tentang hubungan gaya-gaya tersebut saat di ujung pertandingan?
A. $F_{B}>F_{A} ; F_{A}>f_{S B} ; F_{B}>f_{S A}$
B. $F_{B}=F_{A} ; F_{A}<f_{S B} ; F_{B}>f_{S A}$
C. $F_{B}>F_{A} ; F_{A}=f_{S B} ; F_{B}>f_{S A}$
D. $F_{B}=F_{A} ; F_{A}>f_{S B} ; F_{B}>f_{S A}$
E. $F_{B}>F_{A} ; f_{S A}<f_{S B}$

Gambar 9. Soal nomor 24 untuk mengukur pemahaman tentang hukum III Newton

Dalam persoalan yang diberikan anak B berhasil memenangkan pertandingan. Sebanyak 25 (54,35\%) mahasiswa berpikir bahwa pada kasus tarik tambang, tarikan anak yang menang dalam permainan lebih besar dari tarikan anak yang kalah (Gambar 9). Alasan ini menunjukkan bahwa mahasiswa belum memahami secara benar konsep gaya yang merupakan hasil interaksi antara dua objek akan menghasilkan gaya yang sama besar. 


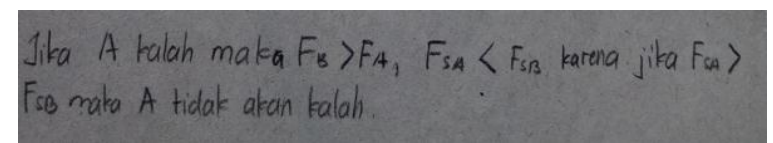

Gambar 10. Kesalahan umum mahasiswa dalam menjawab soal nomor 24

Gambar 10 menunjukkan kebanyakan alasan yang diberikan oleh mahasiswa dalam menjawab soal nomor 24. Opsi B merupakan jawaban yang benar pada soal ini. Namun hanya $5(10,87 \%)$ mahasiswa yang memilih opsi B. Selain opsi D, $4(8,69 \%)$ mahasiswa memilih opsi $A$ dan 8 (17,39\%) mahasiswa memilih opsi $C$ yang juga mewakili pemikiran bahwa gaya tarik $B$ lebih besar dari pada gaya tarik $A$.

Pemikiran demikian ini umum terjadi karena dalam memahami konsep gaya, kebanyakan mahasiswa berpikir bahwa gaya hadir berdasarkan 'kekuatan' yang bergantung dari benda atau objek, dan bukan merupakan hasil interaksi (Brown, 1989). Oleh karena itu pembelajaran terkait konsep gaya akan lebih baik jika disampaikan dengan membangun pemahaman mahasiswa dari memperkenalkan interaksi antar objek (Brown, 1989; Hellingman, 1989; Jiménez \& Perales, 2001; Reif et al., 1992; Rosengrant et al., 2009; Savinainen et al., 2013). Hal tersebut merupakan salah satu cara untuk membangun free-body diagrams dengan benar, sehingga dalam mengidentifikasi gaya akan memperkecil kemungkinan kekeliruan yang mungkin dialami oleh mahasiswa.

\section{KESIMPULAN}

Dari hasil dan pembahasan yang telah dipaparkan sebelumnya, maka dapat disimpulkan bahwa penguasaan konsep mahasiswa terkait topik gaya dan gerak masih rendah. Hal ini ditunjukkan dari nilai rata-rata mahasiswa yang masih rendah, yakni 30,35. Selain itu, respon yang diberikan oleh mahasiswa banyak yang keliru. Hal tersebut menunjukkan adanya kesulitan dalam memahami konsep gaya dan gerak. Beberapa kesulitan yang banyak terjadi dianntaranya dalam menggambarkan arah gaya normal, memahami konsep hukum II Newton karena kesalahan dalam menentukan arah percepatan, kesalahan dalam menggambarkan free-body diagram dan mebandingkan gaya hasil interaksi karena kesalahan dalam memahami hukum III Newton.

\section{SARAN}

Penelitian ini membidik pemahaman konsep mahasiswa pada topik gaya dan gerak. Meskipun sudah banyak temuan-temuan terkait kesulitan mahasiswa pada topik yang sama, namun penelitian seperti ini masih perlu dilakukan. Hal tersebut mengingat pentingnya mengidentifikasi pemahaman konsep mahasiswa sebelum pembelajaran untuk memaksimalkan rencana dan proses pembelajaran. Diharapkan penelitian dalam mengungkap dan memetakan pemahaman mahasiswa terus dilakukan pada topik-topik lain dalam fisika untuk memperkaya temuan-temuan yang berguna dalam pembelajaran. Dalam penelitian ini, kesalahan-kesalahan dalam menyelesaikan soal lebih disebut sebagai penyebab kesulitan dalam memahami konsep. Perlu dilakukan penelitian lebih lanjut apakah alasan yang dimiliki merupakan miskonsepsi atau hal lain.

\section{DAFTAR RUJUKAN}

Alias, S. N., \& Ibrahim, F. (2016). A Preliminary Study of Students' Problems on 
Newton's Law. International Journal of Business and Social Science, 7(4), 133-139.

Andre, T., \& Ding, P. (1991). Student misconceptions, declarative knowledge, stimulus conditions, and problem solving in basic electricity. Contemporary Educational Psychology, 16(4), 303-313. https://doi.org/10.1016/0361-476X(91)90011-9

Arief, M. K., Handayani, L., \& Dwijananti, P. (2012). Identifikasi kesulitan belajar fisika pada siswa RSBI: studi kasus di RSMABI Se-Kota Semarang. UPEJ: Unnes Physics Education Journal, 1(2), 5-10. Retrieved from http://journal.unnes.ac.id/sju/index.php/upej

Azizah, R., Yuliati, L., \& Latifah, E. (2015). Kesulitan Pemecahan Masalah Fisika pada Siswa SMA. Jurnal Penelitian Fisika Dan Aplikasinya (JPFA), 5(2), 44-50. https://doi.org/10.26740/jpfa

Başer, M. (2006). Effect of conceptual change oriented instruction on remediation of students ' misconceptions related to heat and temperature concepts. Journal of Maltese Education Research, 4(1), 64-79. https://doi.org/10.1061/(ASCE)07339410(1991)117

Bayraktar, S. (2009). Misconceptions of Turkish pre-service teachers about force and motion. International Journal of Science and Mathematics Education, 7(2), 273291. https://doi.org/10.1007/s10763-007-9120-9

Beynon, J. (1994). A few Thoughts on Energy and Mass. Physics Education, 29, 86-88.

Brown, D. E. (1989). ' $\{$ S $\}$ tudent' Conept of Force: The Importance of Understanding the Third Law. Physics Education, 24, 353-358.

Chambers Andre, T., S. (1997). Gender, prior knowledge, interest, and experience in electricity and conceptual change text manipulations in learning about direct current. Journal of Research in Science Teaching, 34(2), 107-123.

Clement, J. (1982). Students' preconceptions in introductory mechanics. American Journal of Physics, 50(1), 66-71. https://doi.org/10.1119/1.12989

Clement, J., Brown, D. E., \& Zietsman, A. (1989). Not all preconceptions are misconceptions: Finding 'anchoring conceptions' for grounding instruction on students' intuitions. International Journal of Science Education, 11(5), 554-565. https://doi.org/10.1080/0950069890110507

diSessa, A. A. (1993). Toward an Epistemology of Physics. Cognition and Instruction, 10(2-3), 105-225. https://doi.org/10.1080/07370008.1985.9649008

Docktor, J. L., \& Mestre, J. P. (2014). Synthesis of discipline-based education research in physics. Physical Review Special Topics - Physics Education Research, 10(2), 1-58. https://doi.org/10.1103/PhysRevSTPER.10.020119

Dykstra, D. I., Boyle, C. F., \& Monarch, I. A. (1992). Studying conceptual change in learning physics. Science Education, 76(6), 615-652. https://doi.org/10.1002/sce.3730760605

Eshach, H. (2014). Development of a student-centered instrument to assess middle school students conceptual understanding of sound. Physical Review Special Topics $\begin{array}{llll}\text { Physics Education 10(1), Research, 14. } & \text { 10 }\end{array}$ https://doi.org/10.1103/PhysRevSTPER.10.010102

Eshach, H., Lin, T. C., \& Tsai, C. C. (2016). Taiwanese middle school students' materialistic concepts of sound. Physical Review Physics Education Research, 12(1), 1-9. https://doi.org/10.1103/PhysRevPhysEducRes.12.010119

Fisher, K. (1999). Exercises in drawing and utilizing free-body diagrams. The Physics Teacher, 37(7), 434-435. https://doi.org/10.1119/1.880343

Fisher, K. M. (1985). A misconception in biology: Amino acids and translation. Journal of Research in Science Teaching, 22(1), 53-62. https://doi.org/10.1002/tea.3660220105 
Galili, I., \& Bar, V. (1992). Motion implies force: where to expect vestiges of the misconception? Motion implies force: where to expect vestiges of the misconception? International Journal of Science, 14(1), 37-41.

Gilbert, J. K., \& Watts, D. M. (1983). Concepts, Misconceptions and Alternative Conceptions: Changing Perspectives in Science Education. Journal of MarketFocused Management, 10(1), 61-98. https://doi.org/10.1080/03057268308559905

Hair, J. F., Black, W. C., Babin, B. J., \& Anderson, R. E. (2010). Multivariate Data Analysis (7th ed.). New Jersey: Prentice Hall, Upper Saddle River.

Hake, R. R. (1998). Interactive-engagement versus traditional methods: A six-thousandstudent survey of mechanics test data for introductory physics courses. American Journal of Physics, 66(1), 64-74. https://doi.org/10.1119/1.18809

Halloun, I. A., \& Hestenes, D. (1985). Common sense concepts about motion. American Journal of Physics, 53(11), 1056-1065. https://doi.org/10.1119/1.14031

Heller, P., \& Huffman, D. (1995). Interpreting the Force Concept Inventory. The Physics Teacher, 33(Nov.), 503-511.

Hellingman, C. (1989). Do forces have twin brothers? Physics Education, 24(1), 36-40. https://doi.org/10.1088/0031-9120/24/1/311

Helm, H. (1980). Misconceptions in physics amongst South African students. Physics Education, 15(2), 92-105. https://doi.org/10.1088/0031-9120/15/2/308

Hestenes, D., Wells, M., \& Swackhamer, G. (1992). Force concept inventory. The Physics Teacher, 30(3), 141-158. https://doi.org/10.1119/1.2343497

Jiménez, J. de D., \& Perales, F. J. (2001). Graphic representation of force in secondary education: analysis and alternative educational proposals. Physics Education, 36, 227-235. https://doi.org/10.1088/0031-9120/36/3/309

Kusyanti, R. N. T. (2013). Pemahaman Konsep Siswa Setelah Menggunakan Media Pembelajaran Animasi Fisika yang Tidak Sesuai Fisika. Berkala Fisika Indonesia, 5(1), 20-24.

Linuwih, S., \& Setiawan, A. (2010). Latar belakang konsepsi paralel mahasiswa pendidikan fisika dalam materi dinamika, 6, 69-73.

Loverude, M. E., Kautz, C. H., \& Heron, P. R. L. (2003). Helping students develop an understanding of Archimedes' principle. I. Research on student understanding. American Journal of Physics, 71(11), 1178-1187. https://doi.org/10.1119/1.1607335

Minstrell, J. (1982). Explaining the "at rest" condition of an object. The Physics Teacher, 20(1), 10-14. https://doi.org/10.1119/1.2340924

Muthukrishna, N., Carnine, D., Grossen, B., \& Miller, S. (1993). Children's Alternative Frameworks: Should They Be Directly Addressed in Science Instruction? Journal of Research in Science Teaching, 30(2), 233-248. https://doi.org/10.1002/tea.3660300303

Radovanović, J., \& Sliško, J. (2013). Applying a predict-observe-explain sequence in teaching of buoyant force. Physics Education, 48(1), 28-34. https://doi.org/10.1088/0031-9120/48/1/28

Reif, F., Allen, S., Cognition, S., \& Reif, F. (1992). Cognition for Interpreting Scientific Concepts: A Study of Acceleration Linked references are available on JSTOR for this article: Cognition for Interpreting Scientific Concepts: A Study of Acceleration, 9(1), 1-44. https://doi.org/10.1207/s1532690xci0901

Rosengrant, D., Van Heuvelen, A., \& Etkina, E. (2009). Do students use and understand free-body diagrams? Physical Review Special Topics - Physics Education Research, 5(1), 1-13. https://doi.org/10.1103/PhysRevSTPER.5.010108

Savinainen, A., Mäkynen, A., Nieminen, P., \& Viiri, J. (2013). Does using a visual- 
representation tool foster students' ability to identify forces and construct free-body diagrams? Physical Review Special Topics - Physics Education Research, 9(1), 1-11. https://doi.org/10.1103/PhysRevSTPER.9.010104

Sevilla, C. G., Ochave, J. A., Punsalan, T. G., Regala, B. P., \& Uriarte, G. G. (1993). Pengantar Metode Penelitian, Cetakan Pertama (1st ed.). Jakarta: Penerbit Universitas Indonesia (UI-Press).

Stein, M., Larrabee, T. G., \& Barman, C. R. (2008). A study of common beliefs and misconceptions in physical science. Journal of Elementary Science Education, 20(2), 1-11. https://doi.org/10.1007/BF03173666

Sugiyono. (2014). Metode Penelitian Kuantitatif, Kualitatif, dan R\&D. Bandung: Alfabeta.

Taqwa, M. R. A. (2017). Profil Pemahaman Konsep Mahasiswa dalam Menentukan Arah Resultan Gaya. In Prosiding Seminar Nasional Pendidikan Sains (pp. 79-87).

Taqwa, M. R. A., Hidayat, A., \& Supoto. (2017). Konsistensi Pemahaman Konsep Kecepatan dalam Berbagai Representasi. Jurnal Riset \& Kajian Pendidikan Fisika, 4(1), 31-39. https://doi.org/http://dx.doi.org/10.12928/jrkpf.v4i1.6469

Taqwa, M. R. A., Hidayat, A., \& Sutopo. (2017). Deskripsi Penggunaan Program Resitasi dalam Meningkatkan Kemampuan Membangun Free-Body Diagrams ( FBDs ). Jurnal Pendidikan Fisika Tadulako, 5(1), 52-58. https://doi.org/10.22487/j25805924.2017.v5.i1.8411

Thornton, R. K., \& Sokoloff, D. R. (1998). Assessing student learning of Newton's laws: The Force and Motion Conceptual Evaluation and the Evaluation of Active Learning Laboratory and Lecture Curricula. American Journal of Physics, 66(4), 338-352. https://doi.org/10.1119/1.18863

Trowbridge, D. E., \& McDermott, L. C. (1981). Investigation of student understanding of the concept of acceleration in one dimension. American Journal of Physics, 49(3), 242-253. https://doi.org/10.1119/1.12525

Viennot, L. (1979). Spontaneous Reasoning in Elementary Dynamics. European Journal of Science Education, 1(2), 205-221. https://doi.org/10.1080/0140528790010209 